Co-financed by the European Union

\title{
Migration of Indian health professionals to selected European nations: The Case of Denmark, Netherlands, Norway, Sweden
}

\section{Ayona Bhattacharjee}

CARIM-India Research Report 2013/07
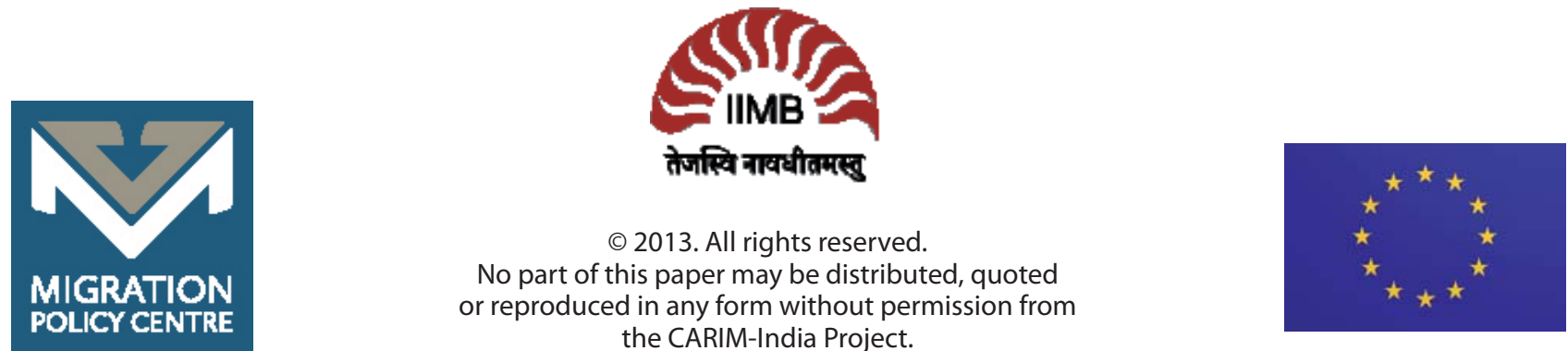


\section{CARIM-India}

Developing a knowledge base for policymaking on India-EU migration

Research Report

Thematic Report

CARIM-India RR2013/07

Migration of Indian health professionals to selected European nations: The Case of Denmark, Netherlands, Norway, Sweden

\section{Ayona Bhattacharjee}

Doctoral student, Economics and Social Sciences Area, Indian Institute of Management, Bangalore, New Delhi 
This text may be downloaded only for personal research purposes. Any additional reproduction for other purposes, whether in hard copies or electronically, requires the consent of the Robert Schuman Centre for Advanced Studies.

Requests should be addressed to India-EU.Migration@eui.eu

If cited or quoted, reference should be made as follows:

Ayona Bhattacharjee, Migration of Indian health professionals to selected European nations: The Case of Denmark, Netherlands, Norway, Sweden, CARIM-India RR 2013/07, Robert Schuman Centre for Advanced Studies, San Domenico di Fiesole (FI): European University Institute, 2013.

THE VIEWS EXPRESSED IN THIS PUBLICATION CANNOT IN ANY CIRCUMSTANCES BE REGARDED AS THE OFFICIAL POSITION OF THE EUROPEAN UNION

European University Institute

Badia Fiesolana

I - 50014 San Domenico di Fiesole (FI)

Italy

http://www.eui.eu/RSCAS/Publications/

http://www.india-eu-migration.eu/publications/

http://cadmus.eui.eu 


\section{CARIM-India - Developing a knowledge base for policymaking on India-EU migration}

This project is co-financed by the European Union and carried out by the EUI in partnership with the Indian Council of Overseas Employment, (ICOE), the Indian Institute of Management Bangalore Association, (IIMB), and Maastricht University (Faculty of Law).

The proposed action is aimed at consolidating a constructive dialogue between the EU and India on migration covering all migration-related aspects. The objectives of the proposed action are aimed at:

- Assembling high-level Indian-EU expertise in major disciplines that deal with migration (demography, economics, law, sociology and politics) with a view to building up migration studies in India. This is an inherently international exercise in which experts will use standardised concepts and instruments that allow for aggregation and comparison. These experts will belong to all major disciplines that deal with migration, ranging from demography to law and from economics to sociology and political science.

- Providing the Government of India as well as the European Union, its Member States, the academia and civil society, with:

1. Reliable, updated and comparative information on migration

2. In-depth analyses on India-EU highly-skilled and circular migration, but also on low-skilled and irregular migration.

- Making research serve action by connecting experts with both policy-makers and the wider public through respectively policy-oriented research, training courses, and outreach programmes.

These three objectives will be pursued with a view to developing a knowledge base addressed to policy-makers and migration stakeholders in both the EU and India.

Results of the above activities are made available for public consultation through the website of the project: http://www.india-eu-migration.eu/

For more information:

CARIM-India

Robert Schuman Centre for Advanced Studies (EUI)

Convento

Via delle Fontanelle 19

50014 San Domenico di Fiesole

Italy

Tel: +390554685817

Fax: + 390554685770

Email: India-EU.Migration@eui.eu

\section{Robert Schuman Centre for Advanced Studies}




\begin{abstract}
India's comparative advantage in health care is due to a large resource pool and competence in English. Indian migration to the US, UK or Australia has been widely studied, but not much attention has been given to the Scandinavian countries. This paper fills the gap by analysing recent trends and prospects for Indian health professionals in Denmark, Netherlands, Norway and Sweden. It combines available data sources, personal communication with different migration boards, interview of two international recruiters and a migrant health professional. Additionally, it looks at Indian R\&D tie ups in the sector with these countries, which have implications for the movement of health professionals. The data indicates that not much migration is happening in spite of the growing demands. On the R\&D front, India has several tie ups with Sweden. Though there have been developments is in Nordic countries, a major hindrance to the movement of Indian health professionals to these countries is language barrier and the lack of recognition of qualifications. The discussion in this study suggests that improving medical education, standards of practice and initiatives in these countries can have favourable effects on emigration and positive spill overs for the Indian health sector as a whole.
\end{abstract}




\section{Acronyms Used}

\begin{tabular}{|c|c|}
\hline AIIMS & All India Institute of Medical Sciences \\
\hline $\mathrm{CBHI}$ & Central Bureau of health Intelligence \\
\hline DIOC-E & Database on immigrants in OECD and non-OECD countries \\
\hline EEA & European Economic Area \\
\hline EU & European Union \\
\hline GDP & Gross Domestic Product \\
\hline HIV/AIDS & $\begin{array}{l}\text { Human immunodeficiency virus infection / Acquired immunodeficiency } \\
\text { syndrome }\end{array}$ \\
\hline IELTS & International English Language testing System \\
\hline IISc & Indian Institute of Science \\
\hline IOM & International Organisation for Migration \\
\hline ISMH & Indian Systems of Medicine and Homeopathy \\
\hline JIPMER & Jawaharlal Institute of Postgraduate Medical Education and Research \\
\hline MBBS & Bachelor of Medicine and Bachelor of Surgery \\
\hline MCI & Medical Council of India \\
\hline MDGs & Millennium Development Goals \\
\hline MOHFW & Ministry of Health and Family Welfare \\
\hline MOIA & Ministry of Overseas Indian Affairs \\
\hline $\mathrm{MoU}$ & Memorandum of Understanding \\
\hline NBHE & National Board for Health Education \\
\hline $\mathrm{NCHRH}$ & National Commission for Human Resources for Health \\
\hline NEAC & National Evaluation and Assessment Council \\
\hline NIHFW & National Institute of Health and Family welfare \\
\hline NIVEL & Dutch Institute for Health Services Research \\
\hline Nordic Countries & Denmark, Finland, Iceland, Norway and Sweden \\
\hline OECD & Organisation for Economic Co-operation and Development \\
\hline $\mathrm{R} \& \mathrm{D}$ & Research and Development \\
\hline SAFH & Norwegian Registration Authority for Health Personnel \\
\hline SSYK & Swedish Standard classification of Occupations \\
\hline UK & United Kingdom \\
\hline US & United States \\
\hline WHO & World Health Organisation \\
\hline
\end{tabular}




\section{Introduction}

Health care delivery being heavily labour intensive depends upon human resources available for utilisation. Health resource availability is in turn determined by demand and supply forces such as variations in morbidity and mortality rates, proportion of health expenditure in Gross Domestic Product (GDP), availability of medical education, training and other socio-economic conditions. Concerns about rising health resource shortage is gaining prominence in developed countries as reduced occupational activities due to ageing population and chronic diseases are increasing the demand for health care relative to available supplies. Thus when domestic supplies fail to cope with growing demands, countries start relying on foreign health professionals as additional resources.Compared to migration in other professions, migration in the health sector has been highly sensitive to country specific regulatory norms. Different economies have different controls especially on health care training, recruitment and employment thereby motivating or hindering migration flows respectively.

\subsection{Context overview}

Opening up country borders to labour migration has pros and cons similar to any general argument for trade liberalisation. Labour migration is also a result of comparative advantage of economies with cheap skilled resource pool. Gains and losses from such movements accrue to both the receiving and the sending countries. Health worker migration is still a debatable topic because of its impact on countries with fragile health systems. On the other hand, as some of the developed countries gain from these additional resources they have expressed growing interests in employing foreign health professionals.The following shows a rising percentage of foreign doctors in the four European countries. The highest increase is observed for Sweden, whereas it remained the same for the Netherlands, at around 6\% and for Norway at around $15 \%$

Figure 1. Share of foreign doctors over time in Denmark, Netherlands, Norway and Sweden

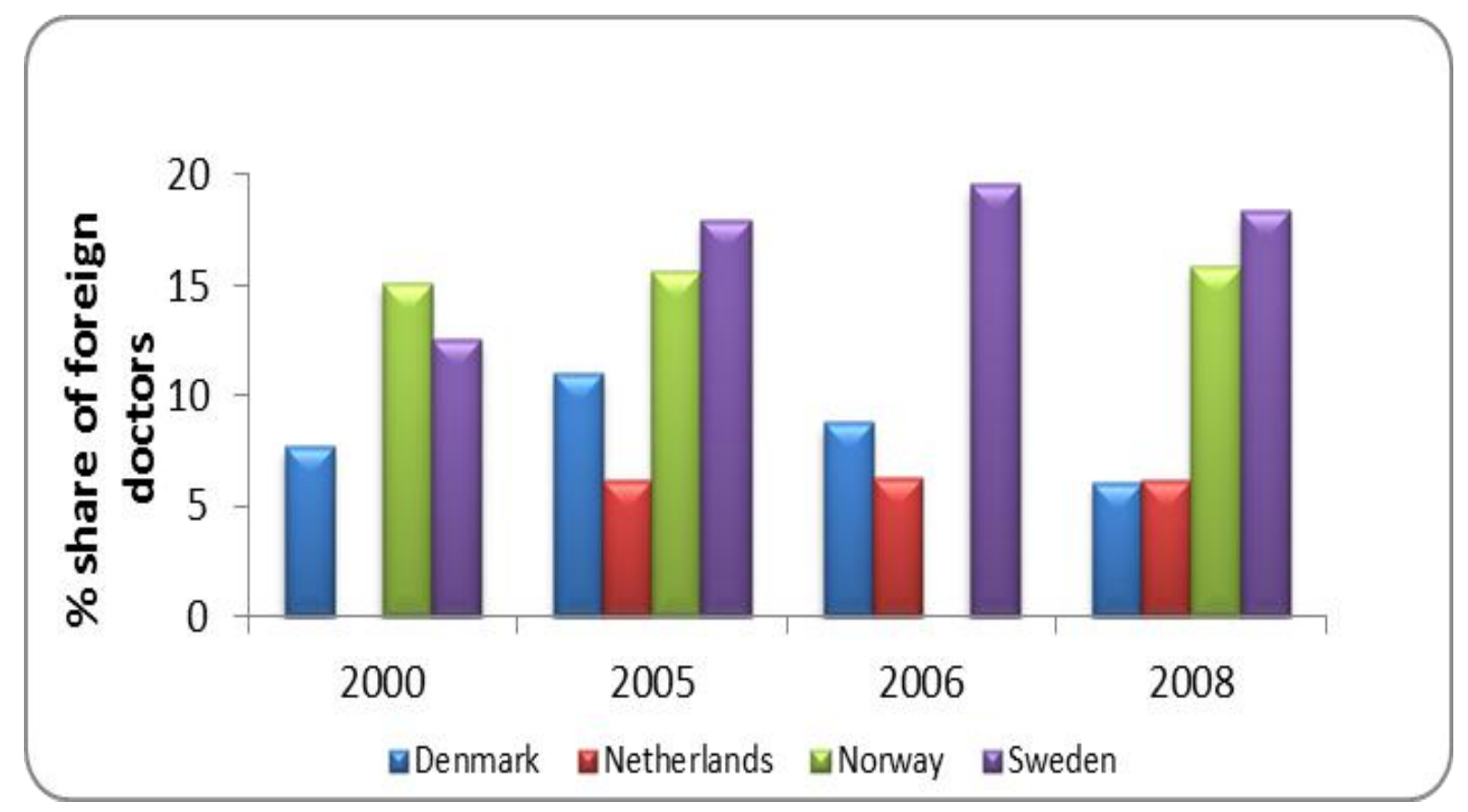

Source- compiled from the Organisation for Economic Co-operation and Development (OECD) database on Practising health professionals by occupation and place of birth in OECD countries 


\subsection{Scope \& outline}

India has held a prime position as a source country in South-Northlabour movement within the health sector. Indian migration to the United States (US), the United Kingdom(UK) and Australia has been studied over the decades, but Indian professionals are fast diversifying their destination countries to avoid repercussions from saturation in these markets. Apart from doctor or nurse migration, the other component of India's relations with these countries is the emerging synergies in health care Research and Development $(\mathrm{R} \& \mathrm{D})$. The Directorate-General for Research in the European Commission and the Department of Science and Technology in India formally renewed the Science and Technology collaboration in 2007, foreseeing mutual gains from rapid globalisation. Indian researchers received attention in the European Union (EU) $6^{\text {th }}$ and $7^{\text {th }}$ Framework Research Programme (FP6 and FP7). This has enabled knowledge transfer, job prospects and exchange programs resulting in labour movement between Europe and India.In spite of migratory flows to the Scandinavian countries, they have generally not been studied much. This paper contributes to the existing literature by studying the current trends and prospects for the Scandinavian countries (Denmark, Norway, and Sweden) and the Netherlands as destinations for Indian health professionals.

The outline of the current paper is as follows: Section 2 presents health care expenditure and resource overview of the 4 selected destination countries and India. Section 3 discusses the migration patterns. Section 4 talks about Indian health professional emigration to these countries. It also goes beyond studying typical health professional migration to see what Research and Development (R\&D) tie ups have developed and are influencing Indian emigration. Section 5 sums up the analysis with some concluding thoughts and observations.

\section{Destination countries versus the Source country}

\subsection{Overview of Health care expenditures\& Resources}

Total health expenditure share of GDP is a proxy for the importance of the sector in that economy. In contrast to India, all the four European destination countries of this study had very high public shares in health expenditure. This brings forward a potential link between the destination public sector and the Indian private sector to cooperate and enable smoother migration process. The disadvantage of public funding for health care is that demand for professionals depends upon economic conditions. This was probably one reason why there was a decline in foreign health professional recruitments in Denmark, after the recent economic downturn. Similar adverse impacts were highlighted when interviewing an international recruiting agency in India.

Figure 2. Public Component in Health Expenditure, (as \% GDP)

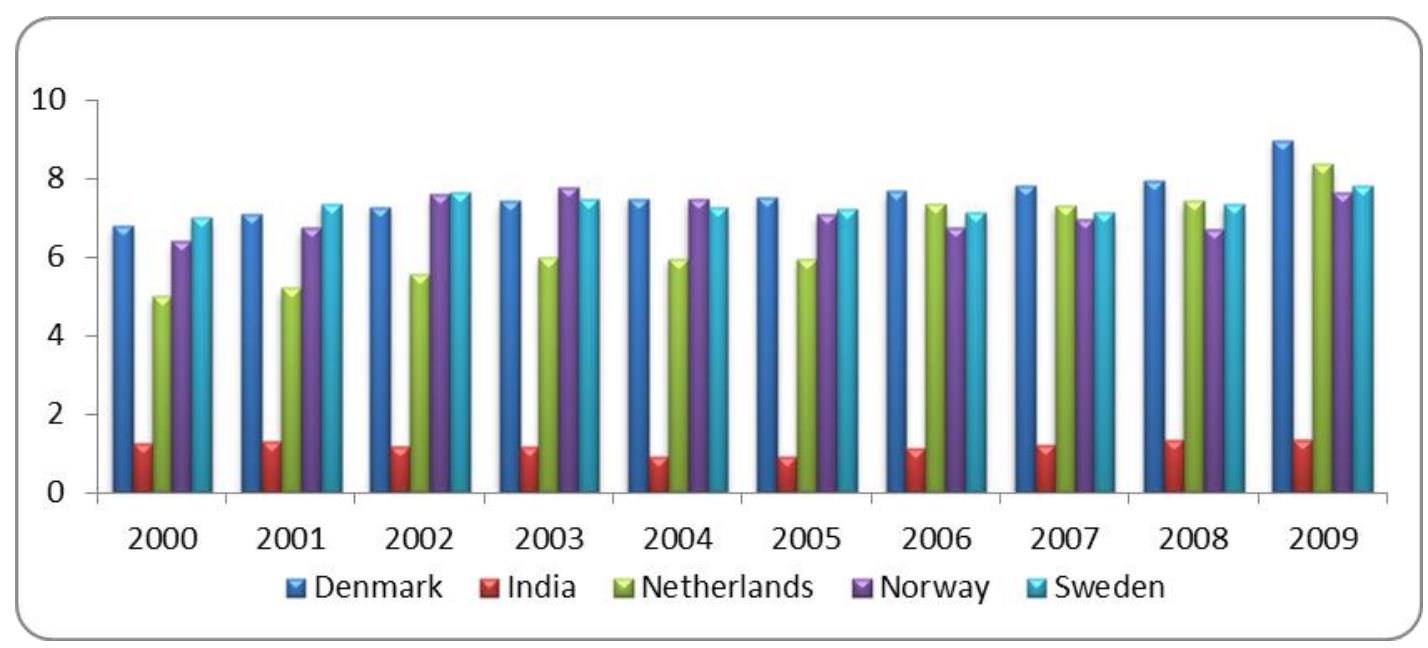

Source- The World Bank database, http://data.worldbank.org/indicator, (accessed $13^{\text {th }}$ March, 2012) 
The following shows health resource intensities in the four countries. All except Netherlands had higher densities than the OECD average (reported in 2009).

Figure 3. Health resource intensities

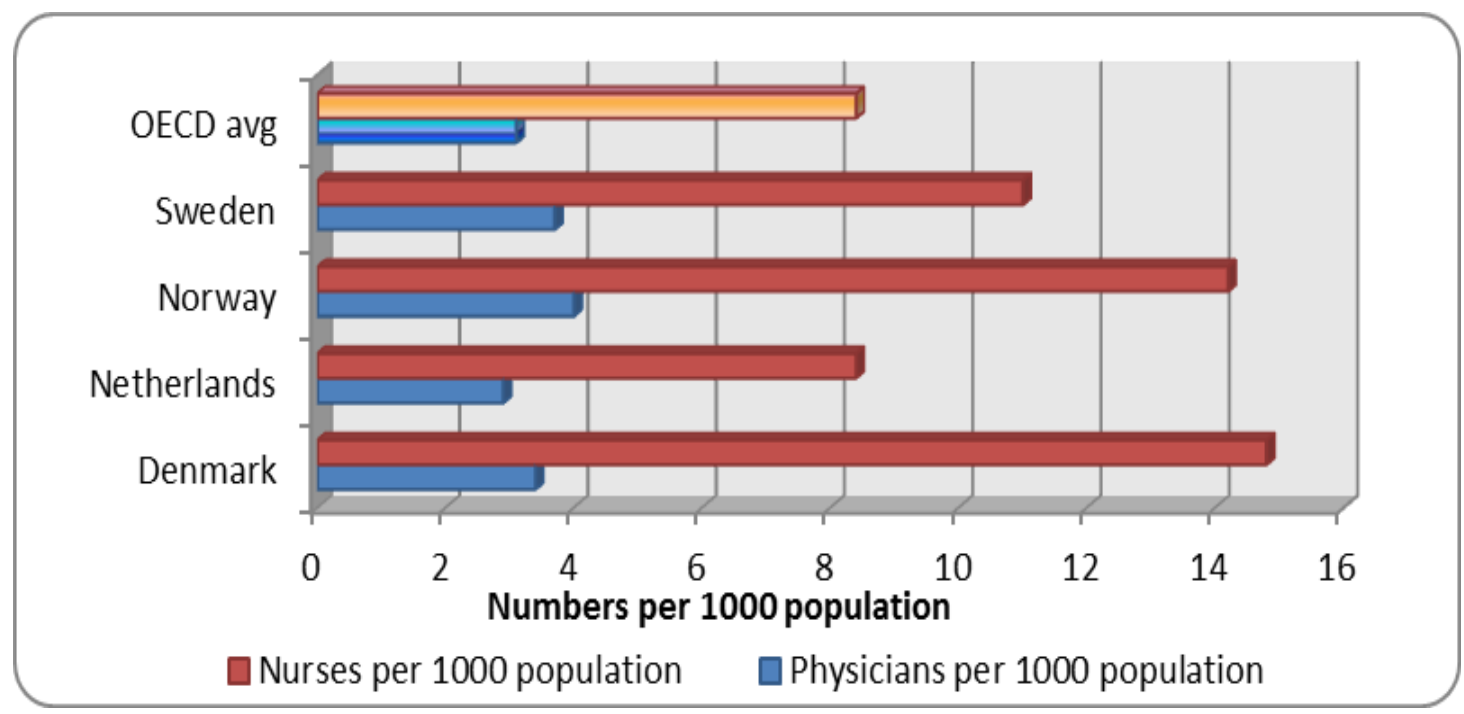

Source - OECD Health Data, 2011 (accessed $23^{\text {rd }}$ March, 2012)

Note: OECD average data is for the year 2009. The data for the four countries is for 2008 except Sweden, 2009

As is evident from the the graphs below, Netherlands had been the lowest performer through out.

Figure 4. Physician and nurse densities over time in the four European countries

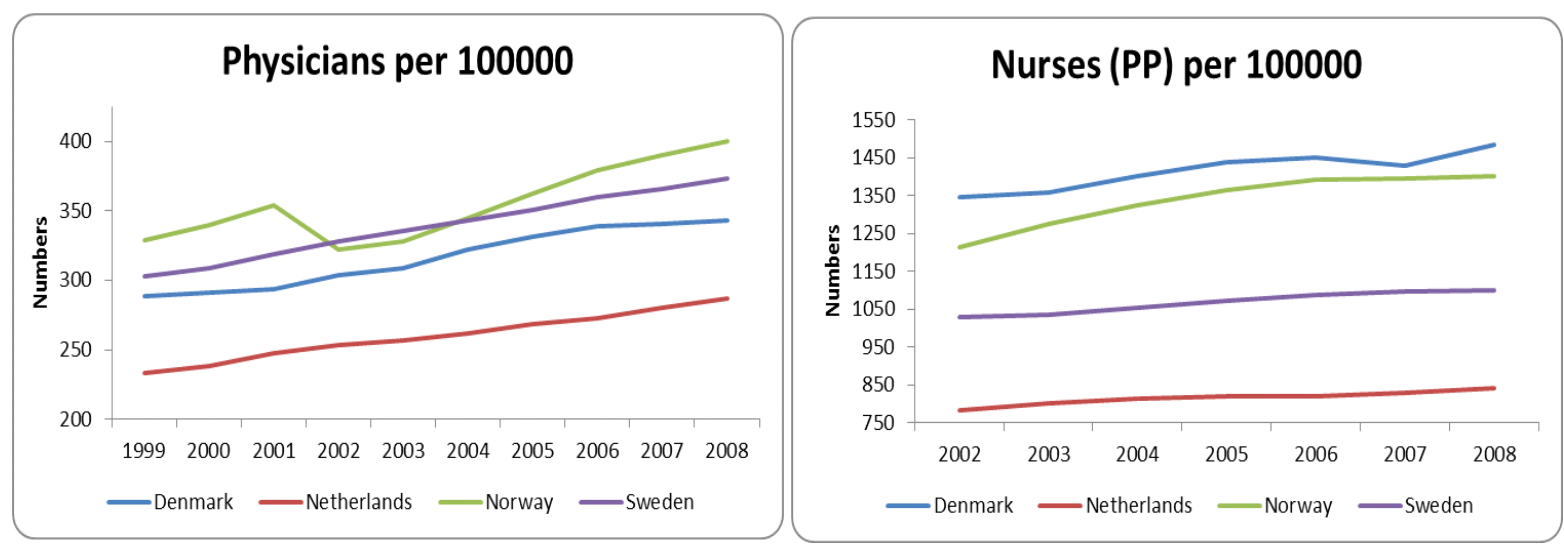

Source- Based on data from http://data.euro.who.int/hfadb/(accessed $6^{\text {th }}$ May, 2012).

(Note - In many cases physicians are not available for medical practice since they work as medical public health officers, researchers, teachers etc.).

The number of physicians and nurses in absolute terms experienced an upward trend in all the four countries, but disaggregation by age groups show striking results. The youngest generation of doctors (less than 35 years of age) and the middle-aged (35 to 54 years of age) have consistently remained low throughout. However, these groups are essential to meet future market demand. The number in the middle age group has been declining in Denmark and Sweden. As the middle age group grows old and the senior doctors retire, it portends an imminent crisis in the future availability of doctors. On the other hand, the ageing population in these countries will require significant medical attention in future. The crisis is further aggravated by emigration from these countries. Around the year 2000, Denmark had the highest number of emigrating doctors and nurses among the four countries. Majority of the doctors from Denmark migrated to Belgium, Ireland, the Netherlands, Germany, Finland, the US, France and the UK. 
Figure 5. Age composition of physicians over time in the four European countries

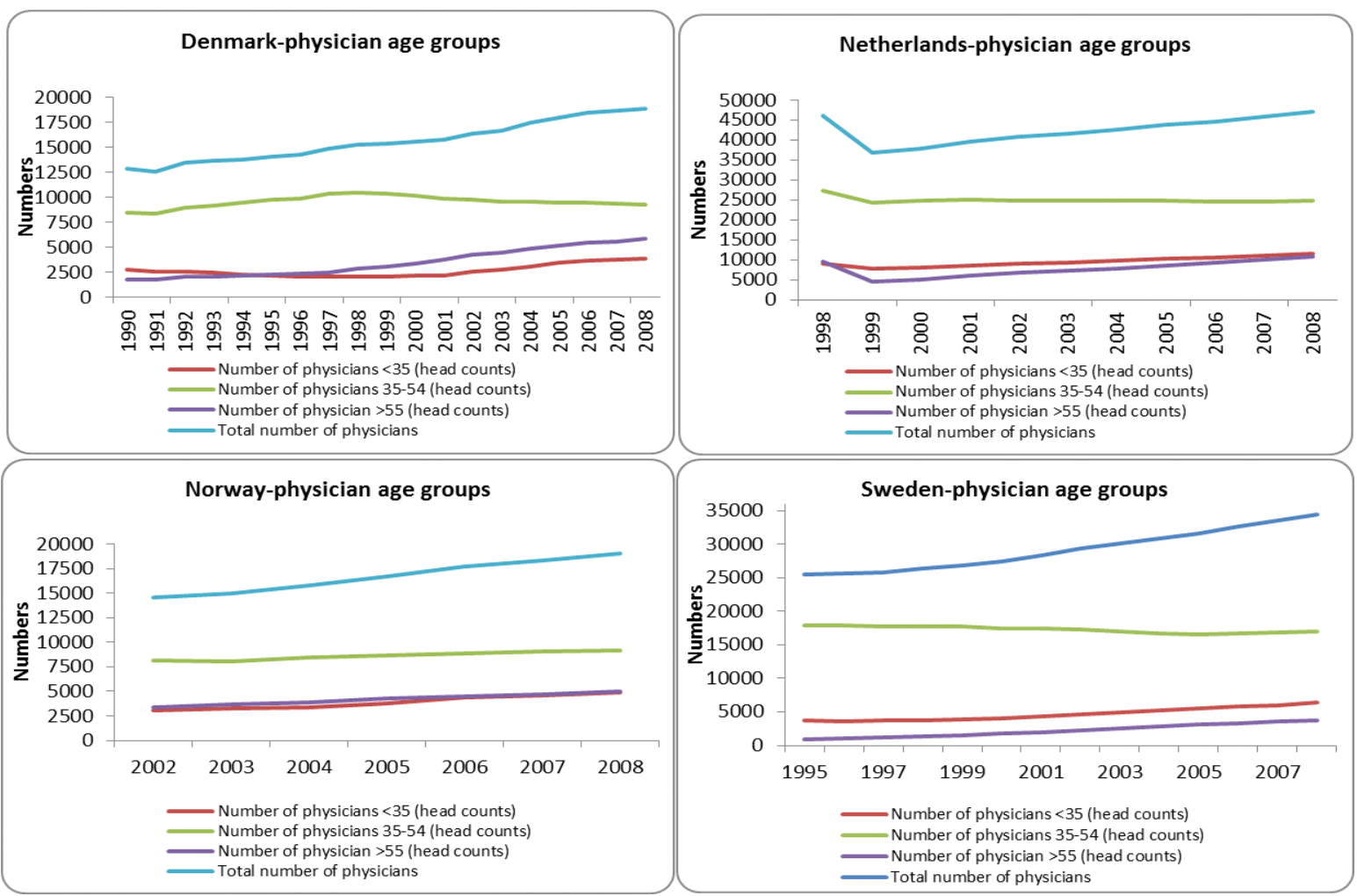

Source -data from http://stats.oecd.org/index.aspx?DataSetCode=HEALTH_STAT, (accessed $6^{\text {th }}$ April, 2012)

It was reported in 2009 that the number of Ischemic heart diseases in Sweden and deaths due to strokes in Denmark were above the OECD average levels. More than 1.7 million people in Denmark suffer from chronic ailments like heart disease, diabetes, cancer, requiring medical attention. It is not just geriatrics gaining importance but other lifestyle diseases that are also contributing to demand for medical care and hence health professionals and research. Health care has been placed in the Danish Positive List, signifying the occupation as not being able to meet the growing demand. A noticeable increase occurred in occupational groups that worked for the aged population in the Netherlands. In 2007, the Netherlands had 324 nursing homes, 960 residential homes and 210 combined institutions, one of the highest among European countries. The Dutch Institute for Health Services Research (NIVEL) developed a workforce forecasting model for doctors in the Dutch health care market. The Capacity Body, set up in 1999 as an advisory body, combines information from the model to propose the number of additional medical specialists required. The enrolment of medical students is controlled by numerus clausus, as advised by the Ministry of Health, Welfare and Sport and set by the Ministry of Education, Culture and Science to ensure cost containment for training doctors. If such cost constraints are to be maintained, it might be cost-effective to recruit foreign professionals rather than building up resources domestically to meet demand. Regiomarge is a special program for the nursing sector covering national, regional and local levels to monitor and forecast the balance between demand and supply of nursing personnel.Shortages of around $40 \%$ in nursing and care have been estimated in Netherlands. CBS Statline reported that during 2000-2008, an average of 6,600 health care and welfare vacancies remained unfilled in Netherlands (Tjadens, 2011).

Around 500 students join the Norwegian medical studies each year thereby limiting the number of possible medical graduates in a year. Statistics Norway along with government agencies framed a model, Helsemod, to forecast demand and supply for Norway's health personnel. Though there are currently no shortages reported, shortages are expected to emerge and affect the sector in future. Calculations from Statistics Norway predicted a total deficit of 43,000 health and social personnel in another 20 years. Sweden's health care sector has 21 professions regulated by legislation through 
authorization. The Swedish Public Employment Service produces occupational forecasts based on interviews with the employers and the councils to understand labour market dynamics of almost 200 occupations. The National Board of Health and Welfare, 2010 reported a fall from 65\% to 50\% in nurses with specialist degrees even though their demands have increased. The largest shortages were reported for specialist physicians, dentists and specialist nurses. Newly graduated occupational therapists and physiotherapists are relatively more in supply (Svensson, Gustafsson, \& Kaplan, 2011).Indices are used to identify professions suffering from shortages and the Swedish Migration Board uses the shortage list to grant work permits.

\subsection{The Indian System}

Apart from growing domestic demands, employment prospects abroad has made healthcare a lucrative career in India. The Indian healthcare sector is estimated at US $\$ 40$ billion and employs over four million people, making it one of the largest service sectors in the economy.The health sector in India is predicted to reach US $\$ 79$ billion by 2012 and US\$ 280 billion by 2020, at a CAGR of around $21 \%$. Around $60 \%$ of hospitals, $75 \%$ of dispensaries, and $80 \%$ of qualified doctors are in the private sector in India (Chanda, 2008). The per capita health expenditure (in constant 2005 US\$) has been increasing over time but majority of the expenditure is borne by private sources. Observing the increasing role of private sector in health care, the public sector is also showing interests in Public-Private partnerships.

Figure 6. Indian Health expenditure composition and trends

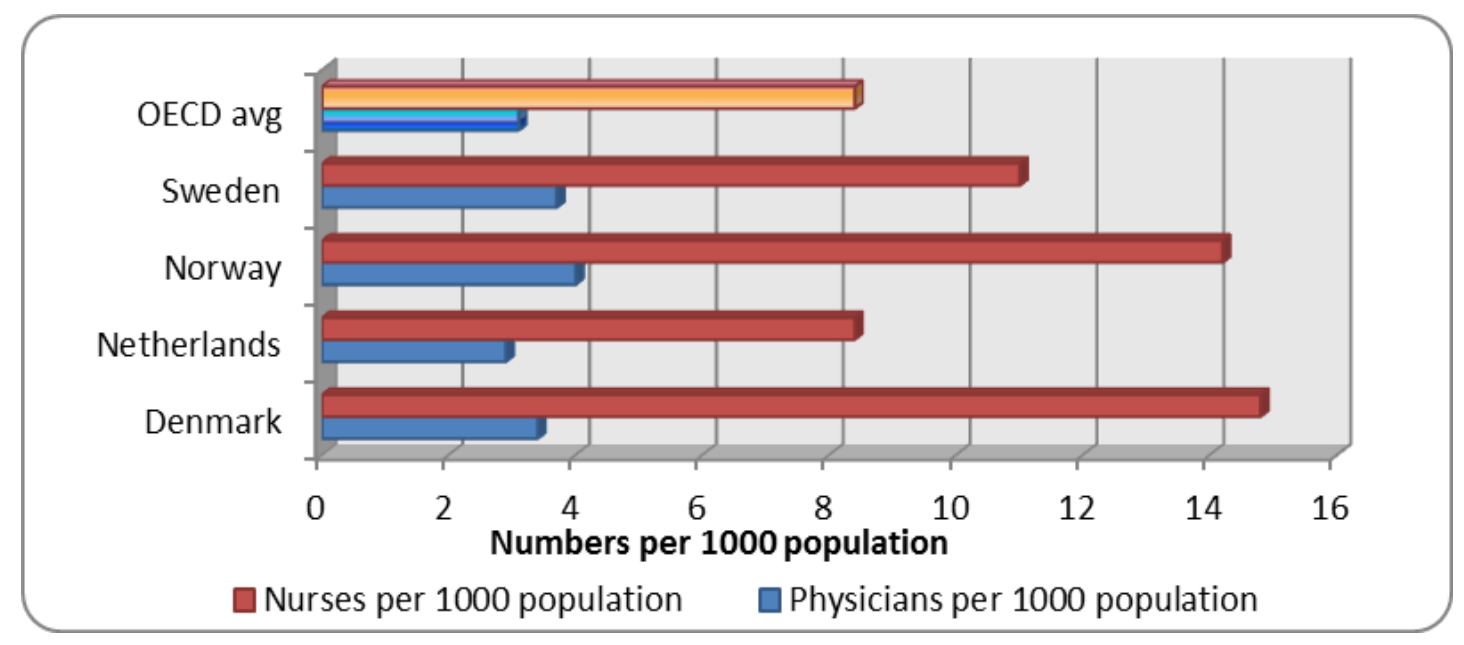

Source- Compiled from the World Bank database (http://data.worldbank.org/indicator, (accessed $13^{\text {th }}$ March, 2012)

The modern system of medicine or Allopathy and the Indian Systems of Medicine and Homeopathy (ISMH) for Ayurveda, Unani, Siddha and Homeopathy constitute the Indian medical education sector. A common entrance examination across all states and individual state examinations are held for admissions into medical colleges. Bachelor of Medicine and Bachelor of Surgery (MBBS) is the undergraduate degree offered in Allopathy medical training on completion of $4 \frac{1}{2}$ years of coursework followed by one year of internship. ISMH bachelor degrees are offered on successful completion of 5 $\frac{1}{2}$-years of training. The Medical Council of India (MCI) is responsible for maintaining medical education standards and granting recognition to medical institutes and medical degrees granted in India and abroad. Currently in 2012, there are355 registered M.B.B.S. colleges in India (with 43,670 total seats), of which 177 were established in the last decade alone. Maharashtra, Karnataka, Tamil Nadu and Andhra Pradesh contributed around $49 \%$ of the total number of colleges in 2011. The Indian Nursing Council (INC) is responsible for maintaining the standard of nursing education and registration of nurses in India. Of all nursing institutes during 2004-2011, 40\% were for GNM, followed by B.Sc. institutes. The highest increase in the number of institutes was for MSc. and P.B.BSc. In 2011, Karnataka, Andhra Pradesh, Tamil Nadu and Kerala had the highest number of nursing institutes. 
Figure 7. Count of MBBS colleges and increase in Nursing institutes in India

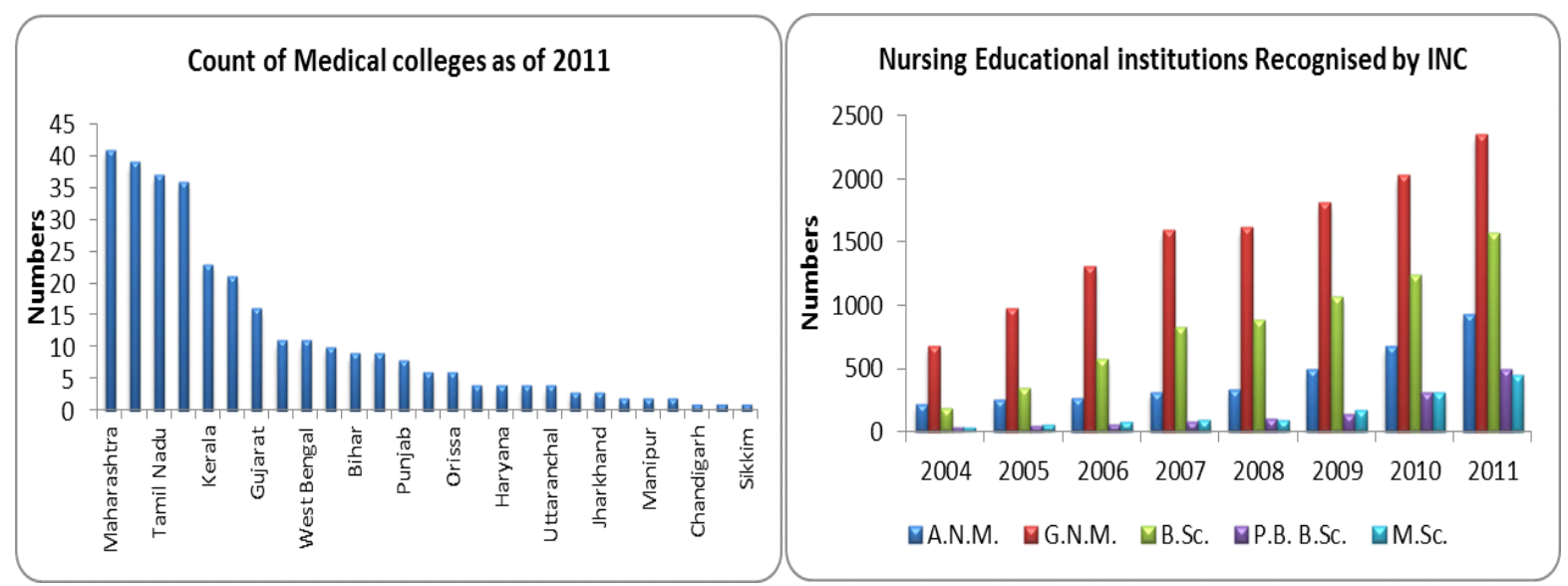

Source- www.indiastat.com, (accessed $12^{\text {th }}$ May, 2012); fig.2 used available data from INC on 24 states only

Due to public budget constraints, most of the institutes are now being set up by private bodies. The MCI data in 2011 showed 54\% of M.B.B.S. student intake was by privately managed institutes. The number of recognised allopathic doctors per 1,000 population shows Karnataka, Punjab, Maharashtra, Tamil Nadu with high numbers. State-wise nurse density per 1000 population is highest in Kerala, Tamil Nadu. Smaller states like Goa and Sikkim have high densities due to a relatively low population base whereas West Bengal and Uttar Pradesh have low densities due to a large population base.

Figure 8. Physician and nurse densities per 1000 population in India

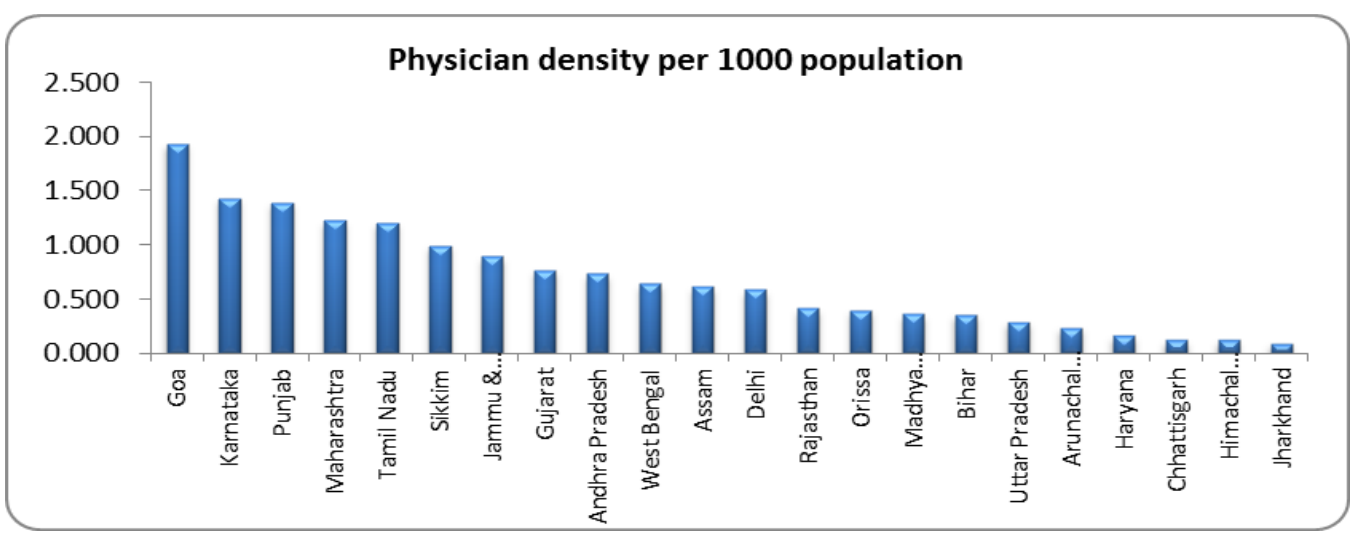

Source-computed from Indiastat.com database and using Census 2011 population data

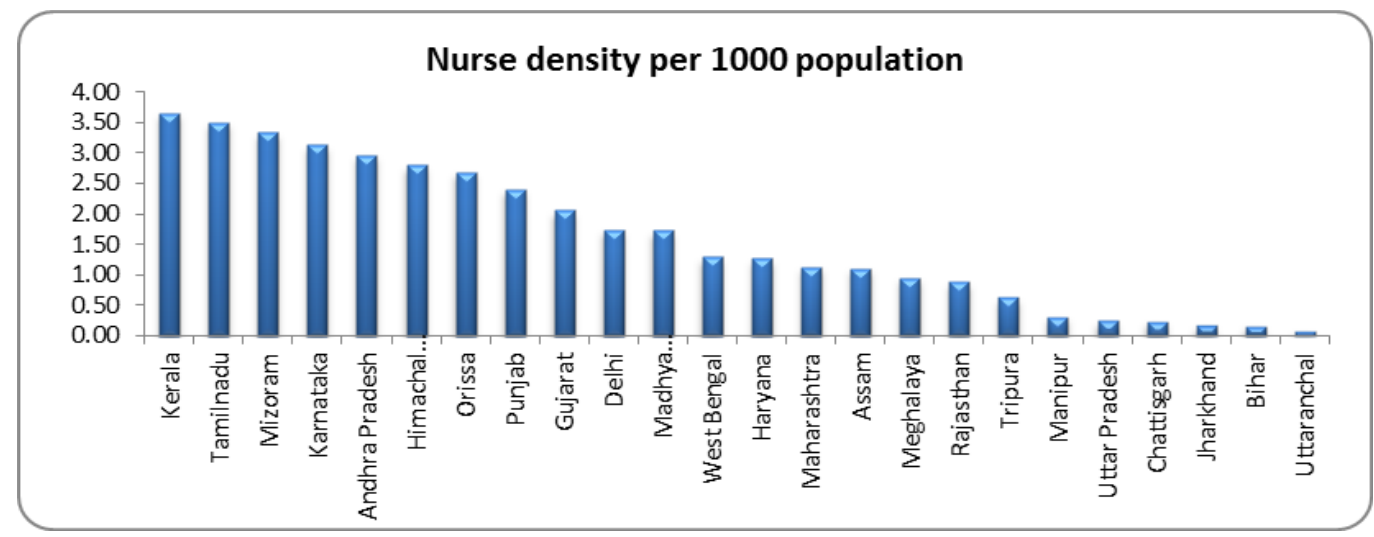

Source- Computed from the INC database and using Census 2011 population data 
Tamil Nadu, Karnataka and Punjab not only have highest number of doctors and nurses but also experience more number of international recruitments compared to other states. The latest development on the Indian health care front has been the National Commission for Human Resources for Health Bill (NCHRH, 2011). It aims to regulate the standard of health education in the country. The Indian Nursing Council Act, 1947; the Pharmacy Act, 1948; the Dentists Act, 1948 and the Indian Medical Council Act, 1956 are likely to be repealed as a result. The NCHRH, National Board for Health Education (NBHE) and the National Evaluation and Assessment Council (NEAC)are being established. The NCHRH will determine and maintain the minimum standard of human resources in health education through assessment of the need for human resources in states; provide grants to the NBHE, NEAC and councils, and regulate the entry of foreign institutions in consultation with NBHE. To prevent dilution of the education system, the NCHRH will work with NEAC in permitting new medical institutes. The NBHE will do the needful to facilitate studies and research in emerging areas of health education. Stricter norms and tests will be implemented for practitioners before they enrol for any professional council. An Indian citizen who wishes to study medicine abroad will henceforth need eligibility certificates from the NBHE. Issues of patient safety are likely to be made stricter since a person wronged by an enrolled medical practitioner can file a complaint with the state council within 60 days.This can inculcate efficient and ethical modes of medical practices in India, to be in line with practices abroad.

\section{Health professional Migration patterns into the 4 European countries}

Depending on different political relations that a country shares with other countries, different rules become applicable for recognition of foreign qualification and labour movements. Denmark signed agreements in 1989 for the European Union (EU) citizens and another in 1993 for the Nordic (Denmark, Finland, Iceland, Norway and Sweden) citizens to provide easier labour market access to the Danish citizens. Doctors from countries apart from these, including India are termed as the "Third country doctors". Their medical degrees need authorization for work permits since they are not privileged to get automatic recognition in Denmark. New registration guidelines introduced in January'11 for medical doctors, made it mandatory to have a positive assessment of medical qualification before participating in examinations. This was aimed to ensure patient safety issues which is at times assumed to be threatened by foreign professionals as they have different standards of practice. After approval of the foreign medical qualification and before the adaptation period starts, there are Danish language tests, Danish medical knowledge tests and a course on Danish health legislation to be completed. Successful completion of 6 or 12 months adaptation employment leads to Danish authorization. The other alternative is to opt for the Green card scheme. This allows a three-year residence permit to be issued to one looking for employment in Denmark. The criteria are usually language skills, work experience, age and extra points for applicants of the positive list. Though human resources are required in Denmark, the new system with its linguistic criteria has made immigration of third country doctors more difficult.

Likewise, it is much easier for health professionals from other EU member states to get employment in Netherlands since in accordance with the EU guidelines, their degrees are considered at par (mutual recognition of professional qualifications, Directive 93/16/EEC and Directive 2005/36/EC). Belgian and German migrants account for almost $60 \%$ of doctors and $23 \%$ of nurse inflows to Netherlands.Many of the immigrants are actually Dutch medical students who entered Belgian medical studies to avoid numerus clausus. Language is a barrier for Netherlands also. Dutch is hardly spoken outside Belgium, Suriname, Dutch Antilles and South Africa. Third country professionals are required to meet the prescribed levels of Dutch language competency and to have knowledge of basic facts and history of the Netherlands. The Netherlands is working to reduce the current two-stage document submission procedure for entry visa and residence permit into one simple step to make the immigration less cumbersome.

Through the European Economic Area (EEA) accord and the Nordic Agreement, Norway accepted agreements regarding mutual recognition of authorisation, licensing, and Certificates of Completion of Specialist Training. The Norwegian Registration Authority for Health Personnel (SAFH) does not 
consider language as a prerequisite for issuance of licence but makes it the employer's responsibility to equip the health personnel with the language. Nursing applicants may be required to undertake supplementary training in Norway if their training standards diverge from the Norwegian system. SAFH issues authorization subject to recognition of medical degrees; work experience and age less than 75 years.Significant contributors of physicians and nurses to the 4 European countries in terms of the percentage of total physician and nurse immigration are,

Table 1. Physician \& nurse Immigration to the four European countries Top 5 physicians contributors to the 4 destinations -

\begin{tabular}{|c|c|c|c|c|c|c|c|}
\hline \multirow{5}{*}{ Denmark } & Germany & \multirow{5}{*}{ Netherlands } & Belgium & \multirow{5}{*}{ Norway } & Denmark & \multirow{5}{*}{ Sweden } & Poland \\
\hline & Sweden & & Germany & & Germany & & Iran \\
\hline & Norway & & Poland & & Sweden & & Finland \\
\hline & Iran & & South-Africa & & USA & & Germany \\
\hline & Iraq & & Italy & & UK & & Denmark \\
\hline
\end{tabular}

Top 5 contributors for nurses to the 4 destinations -

\begin{tabular}{|c|c|c|c|c|c|c|c|}
\hline \multirow{5}{*}{ Denmark } & Norway & \multirow{5}{*}{ Netherlands } & Germany & \multirow{5}{*}{ Norway } & Sweden & \multirow{5}{*}{ Sweden } & Finland \\
\hline & Sweden & & Belgium & & Denmark & & Iran \\
\hline & Germany & & Philippines & & Finland & & Norway \\
\hline & $\begin{array}{l}\text { Great- } \\
\text { Britain }\end{array}$ & & Indonesia & & USA & & Poland \\
\hline & Finland & & Suriname & & Philippines & & Denmark \\
\hline
\end{tabular}

Source - www.oecd.org/health/workforce, (accessed 10 $0^{\text {th }}$ April, 2012); Based on Dumont J-C and Zurn P. (2007).

Sweden has been following an interesting foreign recruitment pattern through its counties. Kalmar County council recruits from Netherlands, Germany. It has its own recruitment agency, Kalmena Rek in Poland for direct recruitments. Stockholm council prefers to recruit nurses from the EU/EEA countries. Kronoberg council recruits doctors from Germany, Poland and Hungary. The Örebrocounty recruits foreign doctors from Poland. The Gävleborg County suffers from a shortage of general practitioners but does not recruit from third countries. The Region of Skåneis relatively less active in recruiting foreign doctors or nurses but uses internships to fill vacancies. The region of Västra Götaland recruits doctors from Germany, Hungary, Netherlands and Spain. These patterns show a clear preference for recruiting from European nations.

There are numerous other regulations specifying standards, eligibility and registration requirements, language certification, and permit issues for healthcare providers in these countries. None of the 4 countries follow the code of conduct for international health professional recruitments unlike New Zealand or the UK. Characteristics of migration policies and recognition systems from the OECD migration report have been provided below. 
Table 2. Migration related clauses in the four European countries for health professionals

\begin{tabular}{|c|c|c|c|c|}
\hline & Denmark & Netherlands & Norway & Sweden \\
\hline $\begin{array}{l}\text { Permanent } \\
\text { migration } \\
\text { programmes } \\
\text { relevant for } \\
\text { health } \\
\text { professionals }\end{array}$ & $\begin{array}{l}\text { Permanent } \\
\text { Residence permit } \\
\text { (after } 7 \text { years ) }\end{array}$ & $\begin{array}{l}\text { Permanent residence } \\
\text { permit (after } 5 \text { years } \\
\text { of residence) }\end{array}$ & $\begin{array}{l}\text { Permanent residence } \\
\text { permit (after } 3 \text { years } \\
\text { of temporary permit) }\end{array}$ & $\begin{array}{l}\text { Permanent } \\
\text { Residence Permit }\end{array}$ \\
\hline Quota & No & $\begin{array}{l}\text { No, except for } \\
\text { Bulgaria and } \\
\text { Romania nationals }\end{array}$ & $\begin{array}{l}\text { Yes, but if the quota } \\
\text { is full, a permit can be } \\
\text { granted under strict } \\
\text { conditions }\end{array}$ & No \\
\hline $\begin{array}{l}\text { Are health } \\
\text { professionals in } \\
\text { Shortage } \\
\text { occupation list }\end{array}$ & $\begin{array}{l}\text { Doctors and } \\
\text { nurses are } \\
\text { included in the } \\
\text { "positive list" }\end{array}$ & $\begin{array}{l}\text { No, but in some } \\
\text { cases the labour } \\
\text { market test is } \\
\text { exempted for specific } \\
\text { health occupations }\end{array}$ & No & No \\
\hline $\begin{array}{l}\text { Bilateral } \\
\text { agreements } \\
\text { relevant for } \\
\text { recruitment of } \\
\text { health } \\
\text { professionals }\end{array}$ & $\begin{array}{l}\text { No, except with } \\
\text { the EU and the } \\
\text { Agreement on a } \\
\text { Common Nordic } \\
\text { Labour Market }\end{array}$ & $\begin{array}{l}\text { No, except with the } \\
\text { EU }\end{array}$ & $\begin{array}{l}\text { No, except with the } \\
\text { EU and the } \\
\text { Agreement on a } \\
\text { Common Nordic } \\
\text { Labour Market }\end{array}$ & $\begin{array}{l}\text { No, except with the } \\
\text { EU and the } \\
\text { Agreement on a } \\
\text { Common Nordic } \\
\text { Labour Market }\end{array}$ \\
\hline $\begin{array}{l}\text { Language } \\
\text { proficiency test }\end{array}$ & $\begin{array}{l}\text { Yes, for people } \\
\text { trained outside } \\
\text { EU/Nordic } \\
\text { countries }\end{array}$ & Yes & $\begin{array}{l}\text { Yes, for doctors with } \\
\text { a first language other } \\
\text { than Norwegian, } \\
\text { Swedish or Danish }\end{array}$ & Yes \\
\hline $\begin{array}{l}\text { Professional } \\
\text { examination }\end{array}$ & $\begin{array}{l}\text { Doctors and } \\
\text { nurses must } \\
\text { possess an } \\
\text { authorisation } \\
\text { from the National } \\
\text { Board of Health }\end{array}$ & $\begin{array}{l}\text { Foreign-trained } \\
\text { doctors have to pass } \\
\text { knowledge and skills } \\
\text { test. If skills are not } \\
\text { equivalent for an } \\
\text { experienced } \\
\text { professional, he may } \\
\text { be allowed in a } \\
\text { Dutch training } \\
\text { institute }\end{array}$ & $\begin{array}{l}\text { Authorisation is } \\
\text { granted to applicants } \\
\text { who have } \\
\text { successfully } \\
\text { completed service } \\
\text { training }\end{array}$ & $\begin{array}{l}\text { People must present } \\
\text { evidence of } \\
\text { sufficient } \\
\text { knowledge of the } \\
\text { Swedish Language }\end{array}$ \\
\hline $\begin{array}{l}\text { Probation } \\
\text { period Training } \\
\text { programmes }\end{array}$ & $\begin{array}{l}\text { People trained } \\
\text { outside } \\
\text { EU/Nordic } \\
\text { countries must } \\
\text { have qualification } \\
\text { and language } \\
\text { proficiencies } \\
\text { assessed }\end{array}$ & $\begin{array}{l}\text { Yes; international } \\
\text { students after } \\
\text { graduating can stay } \\
\text { for upto } 3 \text { months to } \\
\text { seek a job }\end{array}$ & $\begin{array}{l}\text { If qualification is not } \\
\text { fully equivalent, } \\
\text { bridging courses are } \\
\text { available. Prior work } \\
\text { experience adds no } \\
\text { advantage to the } \\
\text { requirement of the } \\
\text { length of service } \\
\text { licence training }\end{array}$ & $\begin{array}{l}\text { Third country } \\
\text { doctors need to pass } \\
\text { a complementary } \\
\text { training } \\
\text { programme, do } \\
\text { courses, take } \\
\text { language tests }\end{array}$ \\
\hline
\end{tabular}

Source- (Immigrant Health Workers in OECD Countries in the Broader Context of Highly Skilled Migration, 2007), available on http://www.oecd.org/els/internationalmigrationpoliciesanddata/41515701.pdf (accessed $17^{\text {th }}$ April, 2012) 


\section{Emigration of Indian health professionals}

In 2000, the total number of emigrated Indian physicians was about 20,315 and the number of Indian nurses working in the OECD countries was about 22,786. The numbers increased in 2005, with an estimated total of 59,095 Indian medical graduates working in the US, UK, Canada, and Australia.India's Comparative advantage in this process is due to a large resource pool with competence in English. Movement of Indian professionals to the US, UK and Canada over the decades have made Indians one of the most highly recognised groups in those countries. India contributes less than $1 \%$ of doctor or nurse emigration to Denmark and Netherlands. As per the Database on immigrants in OECD and non-OECD countries (DIOC-E) database circa 2000, India ranked $9^{\text {th }}$ as a contributor of doctors and $22^{\text {nd }}$ as a contributor of nurse immigration to Denmark and to Sweden. DIOC-E data around 2000 shows,

Table 3. Indian doctor and nurse migration to countries

\begin{tabular}{|l|r|l|r|}
\hline \multicolumn{2}{|c|}{ Indian Doctor emigration to } & \multicolumn{2}{c|}{ Indian Nurse Emigration to } \\
\hline \multicolumn{1}{|c|}{ Destination } & 298 & UK & Number emigrating \\
\hline UK & 293 & Australia & 215752 \\
\hline Australia & 51 & New Zealand & 330 \\
\hline New Zealand & 13 & Ireland & 294 \\
\hline Portugal & 10 & Portugal & 105 \\
\hline Switzerland & 6 & France & 91 \\
\hline Mexico & 4 & Sweden & 65 \\
\hline Greece & 3 & Switzerland & 51 \\
\hline Denmark & 3 & Austria & 30 \\
\hline Ireland & 1 & Spain & 21 \\
\hline Hungary & 1 & Poland & 19 \\
\hline Austria & 1 & Denmark & 7 \\
\hline France & 1 & Hungary & 21 \\
\hline Spain & & & \\
\hline
\end{tabular}

Source - DIOC-E database, (accessed $6^{\text {th }}$ April, 2012)

The UK has been a preferred destination for years, probably due to the impact of colonial ties, English-speaking population, and similarity in the pattern of education. An agreement was signed between India and UK to enable recruitment of health professionals from India except from Andhra Pradesh, Madhya Pradesh, Orissa and West Bengal since they received development assistance from the UK.The UK government introduced a points-based, five-tiered immigration system with negative implications for third country doctors and nurses in 2008. The cut off for International English Language testing System (IELTS) scores was raised to make immigration more difficult. An acrossthe-board visa clampdown due to the notion that foreign professionals are eating into domestic jobs in the current economic crisis is forcing emigrants to try out less restrictive destinations.

Many health professional recruitment agencies with foreign partnerships were established in India since 2001. Those located in Delhi focus on the U.S. market, those in Kochi and Bangalore focus on nurse migration to the Gulf countries, Australia, New Zealand, Singapore, Ireland, and UK. The agencies usually forward recruitment proposals, seeking agreements and contracts to clients. Clients 
select candidates on the basis of resumes, interview them and forward visa/work permits to the agencies to get the immigration clearance done. The Max Health Staff, the Western International University, Escorts Heart Institute, the Apollo Hospitals, and Jaipur Golden Hospital are some of the large agencies. State governments in Uttar Pradesh, Kerala, Punjab, Tamil Nadu, Karnataka, Himachal Pradesh, Haryana and Delhi have shown interest in facilitating international migration of nurses by setting up State Manpower Export Corporations. Interview with an international recruiter revealed the fact that they find it much harder to place the Indian health professionals in Scandinavian countries.The latter's stringent attitude towards expertise in language acts as the main deterrent. The application procedure for Australia is no less cumbersome since it takes almost 5-6 months to get the first shortlisting done and the whole process is usually never less than a year. Nonetheless, professionals prefer this as a destination as it offers several benefits like free work permits for spouses, high remuneration, and better living standards along with an English speaking population.

Besides other countries, the Ministry of Overseas Indian Affairs (MOIA) has signed bilateral social security agreements with Netherlands (2009), Denmark (2009), Norway (2010) and finalised the draft with Sweden in November2010 to protect the interests of expatriate workers. In addition to social security agreements facilitating migration, a labour mobility partnership was negotiated with Denmark (in Sep'09 though not in force now) and similar agreements are getting finalized with the Netherlands and Norway. The agreement was meant to cater to skilled worker shortage in Denmark by motivating cooperation in the labour market, employment generation, organized migration and information diffusion. It was supposed to provide a direct contact between the employers in Denmark and the recruiting agencies in India. Joint Working Groups were set up to facilitate political dialogues, trade and investments and research and development. In spite of the initiatives taken to cooperate on migration issues, unfortunately none of the agreements have progressed much and as of now stand "not in force".

\subsection{India \& Denmark}

In 2009, out of the 1,200 new doctors 353 were foreign and 423 of the 2,671 newly recruited nurses were foreign trained in Denmark. Denmark was the first country to introduce an Integration Act in 1999 to provide education and employment opportunities to immigrants and their descendants. An international recruitment plan, "Denmark - a good place to work" was introduced to include initiatives on labour immigrant integration. A recruiting organisation in Denmark, with experience in the health sector was actively involved in recruiting Indian doctors in partnership with the Danish regions. It recruited doctors for Mid Jutland, Zealand and Southern Jutland through advertisements in the Indian newspapers.An Indian doctor from Chandigarh, who migrated five years ago to Denmark, talked about his initial glitches due to the language barrier and the licence examinations that he had to face.

The data for Denmark in this paper was provided by the Danish Health and Medicines Authority. The number of emigrants from India in reality differs from the number of electronic applications recorded. The number of electronic and paper applications also differs, the latter being usually lower. The Danish Health and Medicines Authority process an application only when there is enough documentation to look into. Applications are accepted even if the applicant doesn't have a firm job offer but in 2009, job offer was made a strict criterion to shortlist the large number of nursing applications which poured in due to a campaign launched by The Danish Regions and the Danish Ministry of Foreign Affairs.

Table 4. Electronic applications received for registration in Denmark

\begin{tabular}{|l|r|r|r|r|r|}
\hline & 2007 & 2008 & \multicolumn{1}{|c|}{2009} & \multicolumn{1}{c|}{2010} & \multicolumn{1}{c|}{2011} \\
\hline Medical doctor & 95 & 53 & 85 & 35 & 17 \\
\hline Nurse & 9 & 90 & 6787 & 35 & 34 \\
\hline
\end{tabular}

Source: Danish Health and Medicines Authority - Registration register 2012 
The number of applications for medical doctors has fluctuated slightly but the decline in 2011 was perhaps due to apprehension about the new guidelines. Out of the five years reported above, more nurses than doctors migrated from India to Denmark except in 2007. Registration records show the following:

Table 5. Temporary Registration

\begin{tabular}{|l|r|r|r|r|r|}
\hline & 2007 & 2008 & 2009 & 2010 & 2011 \\
\hline Medical doctor & 2 & 40 & 10 & 5 & 1 \\
\hline Nurse & 1 & 0 & 14 & 3 & 0 \\
\hline
\end{tabular}

Source: Danish Health and Medicines Authority - Registration register 2012Table 6: Permanent Registration

\begin{tabular}{|l|r|r|r|r|r|}
\hline & 2007 & 2008 & 2009 & 2010 & 2011 \\
\hline Medical doctor & 1 & 1 & 27 & 8 & 8 \\
\hline Nurse & & 1 & 2 & 7 & 10 \\
\hline
\end{tabular}

Source: Danish Health and Medicines Authority - Registration register 2012

The Central Jutland Region initiated a project in 2007, for which India trained medical doctors were recruited. A hospital in Horsens, Denmark posted an advertisement in the "Indian Times" for doctors and received 700 applications. The project led to an increase in the number of temporary registrations issued in 2008 and had an effect on the number of permanent registrations in the subsequent years.

Danish educational institutes have been interested in bilateral exchanges with Indian institutions in the fields of Information Technology, economics and health. The Nordic Centre in India, established in 2001, is an example of cooperation in the education and cultural area (source - the Ministry of foreign affairs of Denmark). Though results are not yet evident, this could spell a positive future for the Indian health professionals in accessing Danish labour markets. The business communities are also informed about progress made in health sciences research collaboration so that public-private partnerships can be ushered in, if required. The Scout-India scheme, launched in 2005, allowed mutual exchange programs for research. Stem cell research has been a common topic of interest in both the nations. The Danish Council for Strategic Research's Programme Commission, Disease and Society and Department of Biotechnology in India fund research collaboration within health science and biotechnology. Since the Danish Ministry of Science, Technology and Innovation is interested in knowledge exchange with foreign communities, it is an opportunity for Indian professionals to capture this niche market. China is already a crucial partner for Denmark in technology and innovation including biomedicine and life sciences. In 2009, further collaboration was initiated between Hong Kong and the Danish Agency for Science, Technology and Innovation for biotechnology and medical science.

\subsection{India \& Netherlands}

The immigration data for Netherlands as of 2007 established the prevalence of cultural, colonial and linguistic ties. South Africa and Indonesia had colonial ties and still contribute largely to health professional immigration in Netherlands. Suriname which was a colony till 1976 provided 33 doctors and 199 nurses in 2007. Netherlands Antilles, although a small country in the kingdom of Netherlands, provided 108 nurses in 2007. However, the role of colonial ties in drawing health professionals will gradually die out as the other push and pull factors start gaining grounds. Of the 5800 new medical specialists registered in the Netherlands during 2000-2006, 960 were foreigners. During 2003-05, 
dentists, midwives and medical doctors had high ratio of number of foreigners to those of Dutch origin.Data on sector specific or more country specific migration to Netherlands was not accessible for any detailed comment. On $7^{\text {th }}$ May 2012, it was declared that India and Netherlands will soon sign a Memorandum of Understanding (MoU) for exchange and benefit of nurses for training and service purposes. This could open up frontiers to the Indian health professionals for a more managed and relatively easier migration process to Netherlands. A second generation Indian in the Netherlands runs a company to recruit Indian skilled migrants for the Dutch labour market. The company has even recruited an Ayurvedic doctor from India. A survey in 2011, by a union of theatre assistants revealed that around 88 Indian theatre assistants are working in 14 Dutch hospitals. Unlike the doctors and nurses, since they are not listed as skilled professions, it is much easier to recruit from abroad as and when necessities arise.Three hospitals in Netherlands recently used an intermediary to recruit operation theatre assistants from India.

\subsection{India \& Norway}

In 2009, only $5 \%$ of the Norwegian health workforce consisted of foreign nationals and a very small fraction of it was accounted for by developing countries. Most immigrant health professionals in Norway are from its neighbouring countries. Norway meets its demand from other European countries which in turn resort to developing nations to meet their health workforce demands.A 1992 PubMed paper by Eknes KG and Kristiansen IS studied the presence of foreign doctors in the Norwegian market in face of almost 500 vacant positions for doctors. The paper surveyed 408 immigrant doctors, from the Nordic countries (22\%), West EU countries (37\%), Eastern Europe (19\%), Asia (17\%), America and Africa. Professional problems emerged as less significant than language and social isolation problems.In 2008, two working groups, chaired by the Norwegian Ministry of Foreign Affairs, were appointed to propose measures to address the global health workforce crisis under Norwegian foreign development and policies. The working group met five Norwegian recruitment and placement agencies for health professionals and found that around 50\% of the recruitments were done by specialist health services and the remaining $50 \%$ by the municipalities. Approximately 6845 authorisations were granted to foreign doctors during the period 2001-08 to work in Norway. The largest group within Asia was mainly from Iraq (114), Pakistan (34) and Iran (23). Of the 13,482 authorisations granted to foreign nurses during the same period Sweden, Denmark, Finland and Germany featured the most. The largest contributor from Asia was the Philippines (314 nurses), South Korea (52 nurses), India (42 nurses) and Iran (35 nurses). During 2001-2008, authorisation to 926 auxiliary nurses out of 5661 foreign persons was granted in Norway. The main contributors were Philippines (623), India (128), Iraq (40) and Thailand (38).Norway employed more Indian nurses than Indian doctors. For this paper, Statistics Norway provided information on immigration from India.

Table 7. Number of permits granted to Indian health and social workers

\begin{tabular}{|c|c|}
\hline Year & Number granted \\
\hline 2007 & 15 \\
\hline 2008 & 32 \\
\hline 2009 & 30 \\
\hline 2010 & 32 \\
\hline 2011 & 12 \\
\hline
\end{tabular}

Source-statistikk@udi.no provided the details on (15/05/2012). The numbers provided were the first time or renewed work permit for specialists in the health and social sector. 
Since it is not compulsory for workers to provide information on their sector of employment, many of the work permits get registered without mention of their sectors and give an incomplete picture of immigration. Norway has signed a cooperation agreement with India to focus on Millennium Development Goals (MDGs) 4 and 5 (child and maternal health respectively).Some arrangements could probably be agreed up in this context this to manage health professional migration. Enabling exchange of professionals for knowledge diffusion and work on the MDGs may benefit both countries.

\subsection{India \& Sweden}

The Swedish Migration Board, which is the national authority for issuing visas, work and residence permits and Statistics Sweden, the administrative agency for data of all kinds, are the two government bodies in Sweden providing immigration statistics. Due to the predicted shortage of doctors in Sweden, a large number of foreign doctors received Swedish registrations. The percentage of doctor licences issued to third country professionals has gradually been outnumbered by the percentage of European professional licences.

Figure 9. Doctor Licenses issued to non-Swedes

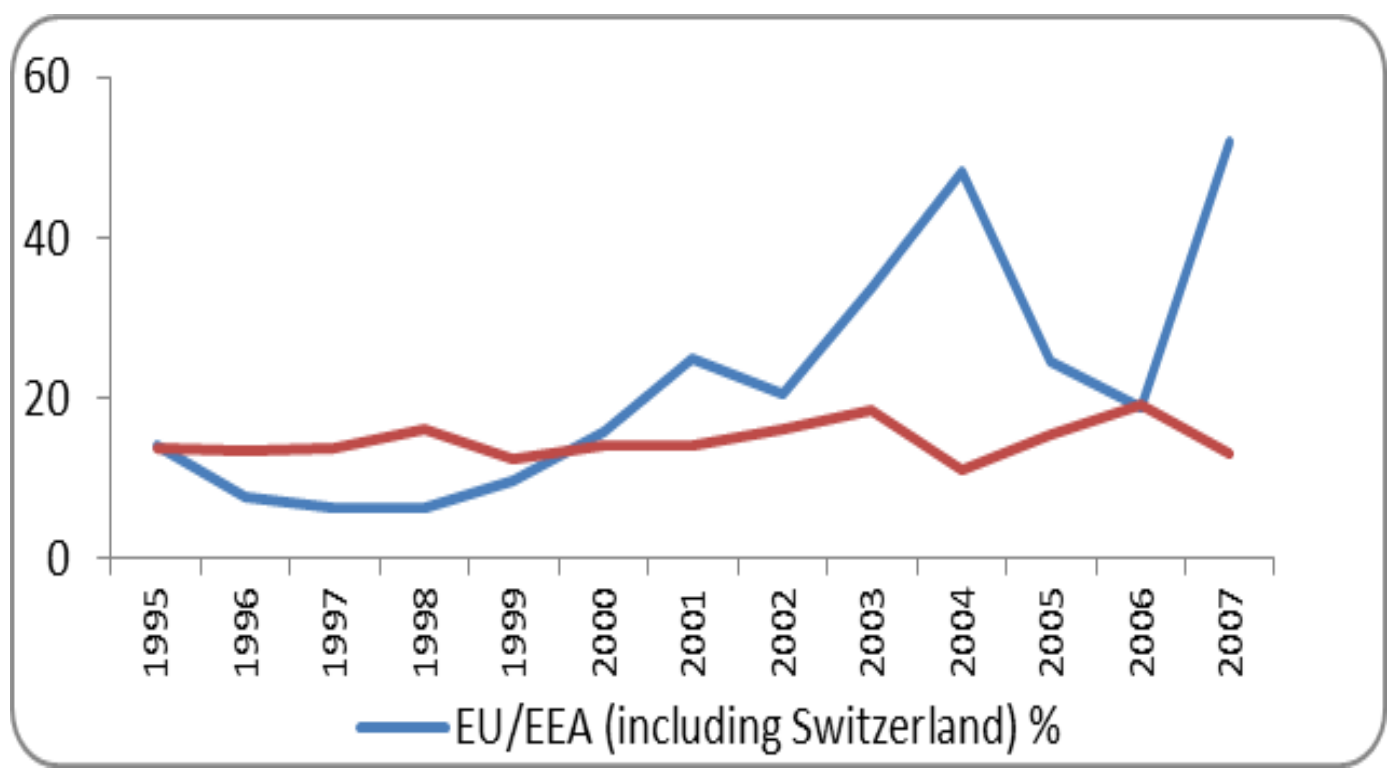

Source - computed from (Svensson, Gustafsson, \& Kaplan, 2011)

Swedish work permits are disaggregated as per the occupational groups and citizenship separately but no joint information is available on the two together. Data for this paper was provided by the Swedish Migration Board.

Work permits: Over the years, Thailand received the highest number, followed by India. Out of 3,782 work permits granted in the first quarter of 2012, the highest was for Indians (899, around $23.77 \%$ of total work permits in that quarter), followed by China (263), and Ukraine (250). Irrespective of citizenship, majority of the work permits were granted to computing professionals, housekeeping and restaurant services workers. Thailand received the highest (2,842 in 2011 and 3,520 in 2010), followed by Indians $(2,292,15.6 \%$ of total work permits in 2011 and 1,853 in 2010).In 2009, India received the second highest number of work permits. Most work permits in the health care domain have been granted to health professionals followed by health associate professionals (except nursing). Lowest number of work permits was recorded by midwifery, nursing professionals and nursing associate professionals. 
Table 8. Summary of number of work permits granted to foreign health professionals in Sweden

\begin{tabular}{|l|l|r|}
\hline \multirow{2}{*}{2012} & Total Health professionals (except nursing) & 6 \\
\cline { 2 - 3 } & Total Nursing and midwifery professionals & 1 \\
\hline \multirow{3}{*}{2011} & Total Health professionals (except nursing) & 50 \\
\cline { 2 - 3 } & Total Health associate professionals (except nursing) & 20 \\
\cline { 2 - 3 } & Total Nursing associate professionals & 6 \\
\cline { 2 - 3 } & Total Nursing and midwifery professionals & 46 \\
\hline \multirow{2}{*}{2010} & Total Health associate professionals (except nursing) & 32 \\
\cline { 2 - 3 } & Total Health professionals (except nursing) & 22 \\
\hline \multirow{2}{*}{2009} & Total Health associate professionals (except nursing) & 35 \\
\cline { 2 - 3 } & Total Health professionals (except nursing) & 1 \\
\hline
\end{tabular}

Source - compiled from the Swedish Migration Board annual reports

Residence permits - In 2012 first quarter, 27,373 residence permits were granted. Out of these, a total of 7,748 residence permits were granted for labour market reasons of which India received 1,477, the highest among the foreign nations. Of the 21,507 labour market residence permits issued in 2010, the highest numbers were acquired by Thailand $(3,613)$, India $(3,016)$ and China $(2,404)$.This clearly shows that though Indians have received fairly high number of residence permits for labour market reasons, the number of work permits granted to overall health professionals is low. So the actual number of work permits received by Indian health professionals is quite low.

Table 9. Work permits for Indian health professionals

\begin{tabular}{|c|c|c|c|c|}
\hline $\begin{array}{l}\text { Swedish Standard classification of Occupations } \\
\text { (SSYK) }\end{array}$ & 2009 & 2010 & 2011 & Total \\
\hline Health professionals (except nursing) & 1 & 2 & 1 & 4 \\
\hline Nursing associate professionals & & & 1 & 1 \\
\hline Personal care and related workers & 7 & 7 & 1 & 15 \\
\hline Total & 8 & 9 & 3 & 20 \\
\hline
\end{tabular}

Source- through email communication with the Swedish migration board, dated-23 ${ }^{\text {rd }}$ April' 12

India had a many personal care workers migrating to Sweden, though they are not clubbed under health services but categorised under service workers as per the Swedish Standard Classification of Occupations. Hardly much nurse migration is observed in this case. A lot is instead being worked upon between India and Sweden to strengthen research ties. The Lund University of Sweden set up the SASNET as collaboration with the Asian countries. The Molecular Immunogenetics lab is working on Diabetes etymology with Cuttack Diabetes Research Foundation in India. Karolinska Institute has tied up with the Thiruvananthapuram Medical College, India and is likely to collaborate with the Vellore Christian College in Andhra Pradesh, India for student and teacher exchange programs. Karolinska Institute had discussions with Biocon to strengthen collaboration, and signed a MoU with the Indian Institute of Science (IISc), Bangalore for cooperation in research and education. A MoU between the Karolinska Institute and the Indian Council of Medical Research was signed in 2009.The Lund University and the National Institute of Health and Family welfare (NIHFW), the Ministry of Health and Family Welfare (MOHFW) and an Indian NGO organised an Indo-Swedish National Training Program on Youth Friendly Health Services in 2011. In February'09, a MoU was signed between the Ministry of Health and Family Welfare, India and the Ministry of Health and Social Affairs in Sweden for cooperation in health care and public health. India is supposed to learn and implement the way Sweden has developed its knowledge in midwifery, nursing skills. It was felt that training the trainers, faculty exchanges, in selected states would be instrumental in augmenting health resources. The Nursing Schools of Chandigarh, All 
India Institute of Medical Sciences (AIIMS), Jawaharlal Institute of Postgraduate Medical Education and Research (JIPMER) and Kolkata were the 4 centres identified for this.

\subsection{R\&D tie ups}

Looking beyond typical doctor or nurse migration, following is a list of current international projects in the health domain that India is working on with organisations from the four nations.

Table 10. List of health science related tie-ups between India and the four European countries

\begin{tabular}{|c|c|c|}
\hline Project Title & Description & Coordinator \\
\hline $\begin{array}{l}\text { Production, delivery of antibody } \\
\text { fragments against gastrointestinal } \\
\text { pathogens by lactobacilli }\end{array}$ & $\begin{array}{l}\text { Aims to study the development and } \\
\text { production of new generation } \\
\text { antibodies }\end{array}$ & $\begin{array}{l}\text { Karolinska Institute, } \\
\text { Sweden }\end{array}$ \\
\hline $\begin{array}{l}\text { The anti retroviral roll out for } \\
\text { (HIV) in India - generating } \\
\text { evidence to promote adherence and } \\
\text { patient follow-up }\end{array}$ & $\begin{array}{l}\text { Aims to conduct research in } \\
\text { (HIV/AIDS), malaria and tuberculosis } \\
\text { between Indian and European partners }\end{array}$ & $\begin{array}{l}\text { Karolinska Institute, } \\
\text { Sweden }\end{array}$ \\
\hline $\begin{array}{l}\text { Developing efficient and } \\
\text { responsive community based micro } \\
\text { health insurance in India }\end{array}$ & $\begin{array}{l}\text { Central Bureau of health Intelligence } \\
\text { (CBHI) looking providing universal } \\
\text { and equitable access to health care }\end{array}$ & $\begin{array}{l}\text { Erasmus University } \\
\text { Rotterdam, } \\
\text { Netherlands }\end{array}$ \\
\hline $\begin{array}{l}\text { Clinical development of a } \\
\text { Pfs } 48 / 45 \text {-based malaria } \\
\text { transmission blocking medicine }\end{array}$ & $\begin{array}{l}\text { Aims for translational vaccine research } \\
\text { for poverty-diseases (HIV/AIDS, } \\
\text { malaria and/or TB) }\end{array}$ & $\begin{array}{l}\text { Radboud University } \\
\text { Nijmegen Medical } \\
\text { Centre, Netherlands }\end{array}$ \\
\hline $\begin{array}{l}\text { Large scale pro-poor programs } \\
\text { focused to reduce maternal } \\
\text { mortality in India }\end{array}$ & $\begin{array}{l}\text { Evaluating two large scale programs, to } \\
\text { decrease maternal mortality for those } \\
\text { below the poverty line in India }\end{array}$ & $\begin{array}{l}\text { Karolinska Institute, } \\
\text { Sweden }\end{array}$ \\
\hline $\begin{array}{l}\text { Asian Regional Capacity } \\
\text { Development for Research on } \\
\text { Social Determinants of Health }\end{array}$ & $\begin{array}{l}\text { Aims to build capacity for health } \\
\text { research and its social determinants in } \\
\text { low and middle income countries }\end{array}$ & $\begin{array}{l}\text { Karolinska Institute, } \\
\text { Sweden }\end{array}$ \\
\hline $\begin{array}{l}\text { Trade, Agriculture Policies and } \\
\text { Structural Changes in India's } \\
\text { Agrifood system; Implications for } \\
\text { National and Global Markets }\end{array}$ & $\begin{array}{l}\text { Analysis of future developments in } \\
\text { Indian supply, demand and trade for } \\
\text { the agricultural commodities and } \\
\text { developments in the food value chain }\end{array}$ & $\begin{array}{l}\text { Landbouw- } \\
\text { Economisch Instituut, } \\
\text { Netherlands }\end{array}$ \\
\hline $\begin{array}{l}\text { Public Perception of Genetically } \\
\text { modified Animals - Science, } \\
\text { Utility and Society }\end{array}$ & $\begin{array}{l}\text { Aims to explore pros and cons and the } \\
\text { public perception of Genetically } \\
\text { Modified animals }\end{array}$ & $\begin{array}{l}\text { Wageningen } \\
\text { University, } \\
\text { Netherlands }\end{array}$ \\
\hline $\begin{array}{l}\text { Jatropha curcas Applied and } \\
\text { Technological Research on Plant } \\
\text { Traits }\end{array}$ & $\begin{array}{l}\text { Link research groups and companies } \\
\text { from different continents to attain } \\
\text { greater synergy in R\&D of jatropha as } \\
\text { a bio fuel crop }\end{array}$ & $\begin{array}{l}\text { Plant Research } \\
\text { International B.V., } \\
\text { Netherlands }\end{array}$ \\
\hline $\begin{array}{l}\text { Impact of Agents with Potential } \\
\text { Use in Functional Foods on } \\
\text { biomarkers for Induction of Age } \\
\text { Related Diseases }\end{array}$ & $\begin{array}{l}\text { Aims to study the protective action of } \\
\text { agents used in the development of } \\
\text { functional foods }\end{array}$ & $\begin{array}{l}\text { Karolinska Institute, } \\
\text { Sweden }\end{array}$ \\
\hline
\end{tabular}

Source -http://ec.europa.eu/euraxess/links/india/collaboration_en.htm, (accessed 21 ${ }^{\text {st }}$ July, 2012) 
The above list of initiatives in R\&D also brings forth possibilities of Indian health professionals in the research fields to travel to the countries. This will contribute to the migratory flows in this sector and at the same time imply mutual gains through knowledge diffusion.

\section{Summary and concluding thoughts}

As always pointed out in the migration literature, there is dearth of data preventing any rigorous analysis in this domain. In the absence of primary data, this study relied on data from published reports and websites. Data on inflows into receiving countries are considered more reliable than data on outflows, since many countries are liable to underestimate the extent of outflows. Different sources from the destination countries such as the Migration Boards, database of registered health professionals, personal communication with the embassies, health ministry reports, annual migration reports and databases like the OECD, World Health Organisation (WHO), World Bank, International Organisation for Migration (IOM) etc. were accessed. Exemption of the skilled workforce from Indian emigration clearance has made it more difficult to come across data on Indian health professional emigration. Language issues were encountered since many reports and websites were in foreign languages. Nonetheless, this paper was based on culling out facts from whatever data was available.

Apart from standard benefits such as gaining remittances, diaspora, knowledge transfers, international relations and investments, the migration process also has other benefits. Skilled worker migration can be a motivation for the others in the same profession to strive and perform better in lure of lucrative jobs abroad. This will result in improved human capital generation and hence higher growth in the sector yielding better performance. Migration would have other spin-offs also. The more renowned the resource pool is, higher would be the attractiveness of the country to foreign patients. Diaspora networking could enable developing prospects for telemedicine. Returnee professionals would add to the expertise of the resource pool. The other aspect could be that a good resource pool would attract more of capital investments since returns increase. This would also have trickle down effects through knowledge transfers, modern equipment, more scientific procedures and so on. Apart from effects on other sectors, migration has strong interlinkages with other modes of service in health sector itself. Globalisation of the education sector could be leveraged by encouraging foreign medical schools to set up training programs in India in languages of the recipient country, as is being done in Jakarta and Bangkok. This will help build up appropriate training standards and suit demands of the recipient countries. Other options could be foreign language classes during graduation or some online training programs with appropriate supervision.

Some of the destination countries are expediting the processes for granting work permits, coordinating recruitment processes to achieve economies of scale and providing space and time for language training, cultural adjustments. Though currently not favoured destinations, predicted shortages in Scandinavian countries may soon make them potential hosts. There are enough opportunities for Indian professionals to explore. One way in which the Indian government could take this forward is by setting up skill augmenting processes. This will help in gaining prospects for mutual recognition of qualifications. There are talks of introducing implicit disincentives for emigrating medical degree graduates. If a medical degree holder from a government institute in India leaves for foreign higher education, he might have to serve in India for three years. Any medical graduate going abroad with a degree from a private institute has to either return to India within three years or inform respective professional councils of his whereabouts. Any deviation from these norms would be considered professional misconduct. Rather than restricting migratory flows like this, the government could take initiatives to mitigate migration losses and help the Indian health system prosper. The positive side in Indian health care is a growing number of international recruitment agencies, medical institutes, standardisation of education and practices posing a promising future for the Indian health workforce whom foreign nations would want to rely upon. 


\section{References}

Anell, A., Glenngård, A. H., \& Merkur, S. (2012). Health Systems in Transition- Sweden Health system review. The European Observatory on Health Systems and Policies.

Buchan, J., Baldwin, S., \& Munro, M. (2008). Migration of health workers: the UK perspective to 2006. Health Working Paper 38., 61.

Chanda, R. (2008). Issues and Concerns in an India-EU Trade and Investment Agreement. ICRIER.

Danish Nurses' Organization, Advanced Nurse Practitioners- improved health care to the chronically ill (2008). Danish Nurses', available on http://www.dsr.dk/Artikler/Documents/Advanced_Nurse_Practitioners.pdf (accessed 26th April, 2012)

Eknes, K., \& Kristiansen, I. (1992).Foreign physicians in Norway. Where do they come from--how do they work--what are their plans for the future? PubMed, 3827-30.

Guidelines concerning the authorization of doctors trained outside Denmark., http://www.sst.dk/ /media/English/Education\%20and\%20authorization/Foreign\%20health\%20pers onal/vejledningeng120705pdf2009.ashx (accessed 5th May, 2012)

Hazarika, I., Bhattacharyya, S., \& Srivastava, A. (2011). India-Mobility of Health Professionals. New Delhi: Institute of Health Policy and Development Studies.

Johnsen, J. (2006). Health systems in transition: Norway. Copenhagen: WHO Regional Office for Europe on behalf of the European Observatory on Health Systems and Policies.

Johnsen, J. R. (2006). Health Systems in Transition.WHO.

Khadria, B. (2007). International nurse recruitment in India. Health Serv Res, 1429-36.

KPMG, ASSOCHAM, Emerging Trends in Healthcare:A Journey from Bench to Bedside, (2011), available http://www.kpmg.com/IN/en/IssuesAndInsights/ThoughtLeadership/Emrging_trends_in_healthcar e.pdf (accessed 20th August, 2012)

Myrvold, K. (2012). Swedish Case Study- Indian Migration and Population in Sweden. European University Institute.

OECD, Immigrant Health Workers in OECD Countries in the Broader Context of Highly Skilled Migration. OECD, Paris (2007), available on http://www.oecd.org/els/internationalmigrationpoliciesanddata/41515701.pdf (accessed 17th April, 2012)

OECD, The Looming Crisis in the Health Workforce. OECD, Paris (2008).

Schäfer, W., Kroneman, M., Boerma, W., Van den Berg, M., Westert, G., W., D., et al. (2010). The Netherlands: Health system review. Health Systems in Transition, 2010; 12(1):1-229. European Observatory on Health systems and Policies.

Svensson, Gustafsson, M., \& Kaplan, D. (2011).Sweden Mobility of Health Professionals. Bonn, , available on http://www.mohprof.eu/LIVE/DATA/National_reports/national_report_Sweden.pdf (accessed 11th August, 2012)

The National Board of Health and Welfare (2010), NPS Arrsrapport 2010.En analysavbarnmorskors, sjuksköterskors, läkares, tandhygienistersochtandläkaresarbetsmarknad. Stockholm: Socialstyrelsen.

Tjadens, F. (2011).The Netherlands- Mobility of Health Professionals. Bonn, available on http://www.mohprof.eu/LIVE/ (accessed 18th May, 2012) 


\section{Other reports}

A proposal for measures under Norwegian foreign and international development policy to address the global health workforce crisis, (2009). Oslo, available on http://www.aspeninstitute.org/sites/default/files/content/images/Proposal\%20for\%20Norway.pdf (accessed 14th May,2012)

European Migration Network Satisfying Labour Demand through Migration, (2010), available on http://www.migrationsverket.se/download/18.6332790112ab7633e5f800010380/EMN+study+Satis fying+Labour+Demand+through+Migration.+Final.+SE+EMN+NCP.Eng..pdf (accessed 23rd April, 2012)

On Progress in the Policy priority of Vocational Education and Training - Norway, (2010).. Norwegian Directorate for Education and Training, available on http://libserver.cedefop.europa.eu/vetelib/2010/vetpolicy/2010_NPR_NO.pdf (accessed 14th May, 2012)

\section{Websites}

http://data.euro.who.int/hfadb/

http://data.worldbank.org/indicator

http://ec.europa.eu/euraxess/links/india/collaboration_en.htm

http://en.fi.dk/international/global-cooperation/denmark-china

http://en.fi.dk/news/news/2008/denmark-and-india-expand-collaboration-on-biotechnologicalresearch-1

http://moia.gov.in/services.aspx $? \mathrm{id} 1=81 \& \mathrm{id}=\mathrm{m} 4 \& \mathrm{idp}=81 \&$ mainid $=73$

http://pib.nic.in/newsite/erelease. aspx $?$ relid=80439

http://www.sarkaritel.com/news_and_features/february2009/25ind_sweden_mou.htm

http://stats.oecd.org/index.aspx?DataSetCode=HEALTH_STAT

http://www.eurotopics.net/en/home/presseschau/archiv/results/archiv_article/ARTICLE20420-

Denmark-recruits-Indian-doctors

http://www.humanr.nl/en/results/

http://www.indiannursingcouncil.org/

http://www.mciindia.org/InformationDesk/MedicalCollegeHospitals/ListofCollegesTeachingMBBS.aspx;

http://www.moneycontrol.com/news/wire-news/india-netherlands-to-sign-mou-for-

exchangenurses_701389.html

http://www.norwayemb.org.in/News_and_events/Development-Cooperation-/NIPI/nipi1/

http://www.prsindia.org/billtrack/the-national-commission-for-human-resources-for-health-bill-2011$2147 /$

http://www.sarkaritel.com/news_and_features/february2009/25ind_sweden_mou.htm

http://www.sasnet.lu.se/sasnet-news

www.indiastat.com

www.oecd.org/health/workforce 